\title{
Prototypical and Categorical Analysis of the Representation of the Family Recomposed by Kassapards
}

\author{
Kabwe Kabela Kankumba Marthe \\ University of Lubumbashi \\ Kassapards: qualifier reserved for the students of the University of Lubumbashi
}

\begin{abstract}
Today, the concept of "representation" is relevant to many disciplines, including psychology, and is applied to many phenomena and institutions including the family. The latter generates a diversity of structures. Of all the structures, this article focuses particular attention on the stepfamily, for many reasons. One of them is related to the extent that this social reality takes overnight in our environment, the province of Upper Katanga and the various issues it raises that are ethical, social and psychological. The dual objective that it pursues is firstly to identify and present in a quantitative way the different representations that students of UNILU produced with regard to the concept of "stepfamily", during a survey carried out on the basis of the 2013 - 2014 academic year. Next, identify the central core as well as the peripheral elements of these purely individual representations elaborated by these students, who daily live the realities of the stepfamily, knowing that the links that an individual has with his family is a limit to his full individuation (Delage, 2008), because we say we are the fruit of our environment. The prototypical and categorical analysis of Vergès (1992) was implemented in the treatment of the collected data. The result of this research is that "living on new foundations" is the central core of a blended family, whose peripheral elements are linked to four essential conditions: historical, emotional, social and ideological.
\end{abstract}

Keywords: Representations - stepfamily - prototypical and categorical analysis

\section{Introduction}

This article provides an illustration of the prototypical and categorical analysis of the representations of the family recomposed by the students of the University of Lubumbashi.

Thus, before demonstrating the methodological approach put in place to study this social phenomenon, it is important to shed light on the readers' opinion regarding the key concepts of this research. The aim is to provide information on the notional approach in relation to family and representation, but also to develop the methodology used in this study, and finally to present and interpret the results.

\section{Notional Approaches}

\subsection{Concepts and issues specific to the family}

Unlike humans, many animal species live and occur without the need to be a family. That is why, "the family today is the object of many attentions, it is enough to see the stalls of the booksellers. We have never written so much about the family as in recent years, sometimes to question its vulnerability, sometimes to specify its evolution and transformations, sometimes to question its very usefulness "(Delage, 2008, p. 7).

Traditionally, the family consists of a triad: father, mother and children (Coslin, 2007). It is considered as all living or deceased persons, living together or not together and connected by biological, sociological, affective or legal ties (Amout, 2005). Leclerco (1958) defines it as the basic cell of a human society, which constitutes for the individual an essential factor of virtue and happiness, on the one hand and on the other, it is par excellence the principle of social continuity and the preservation of human traditions, from which it is the conservative element of civilization. Castellan (1982) considers it to be an ancient institution, which constitutes a fundamental elementary group, and which allows an individual to socialize and live in society.

It should be noted that in previous centuries, it was considered as a basic unit to promote production activities, particularly in the agricultural, artisanal and commercial sectors.

Around the year 1968, the family institution appears as an obstacle to the freedom and the fulfillment of the individual. At present, the family is the natural base of the human community, and is protected by the state and must be organized in such a way as to ensure its unity and stability. As a result, it is no longer seen as a basic social unit, but rather as a social whole (Delage, 2008).

The family plays an important role on the one hand in the social unity and on the other hand in the emotional unity of the elements that interact with one another in an environment and a system. It is considered today as an institution (Delage, 2013) that breaks out into multiple "relational arrangements", to the point that today coexist links that are formed and maintained in marriage, in various configurations related to "Recompositions", and where children can live with one or more parents. They can come and go between different homes, and all of this can change over time in their representation of the family. For most of those who fail in their family are trying to start over and make another family (Delage, 2008: 57).

Duret and Lefebvre (1997: 55) consider that "it is within the family that the adolescent will first seek to question his

\section{Volume 6 Issue 12, December 2017}




\section{International Journal of Science and Research (IJSR) \\ ISSN (Online): 2319-7064}

Index Copernicus Value (2016): 79.57 | Impact Factor (2015): 6.391

sense of self", so we conclude that it is a perfect and par excellence place in which teenagers forge their identity.

In this research, our choice is focused on one of the family structures, called the "stepfamily", and this is justified by the fact that the appearance of the latter becomes frequent and increases overnight in our environment and its surroundings. Several causes supporting this phenomenon have been identified, among which the most recurrent are the socioeconomic-political realities of our province, Haut-Katanga, to which we can associate natural disasters. The province of Upper Katanga is characterized by the mixing of cultures. This is due to modernization and the phenomenon of urbanization, but also to the proliferation of mining companies. All of the aforementioned causes have a considerable impact on agents' salaries, the trend towards homogenization of cultures, which is causing families to lose their values and their benchmarks (Bizige, 2012). Note also that they promote work hundreds of kilometers, and for many days. As a result, in many cases, there is a prolonged absence of one of the parents. All of these arguments contribute to the magnitude of these phenomena in our province. For Kienge-Kienge (2008), the family is the heart of social and political life, and constitutes "the basic unit of education" (Bizige, 2012: 23). Therefore, what society and politics become depends on what families are. To put it simply, stable families are the basis of stable politics and society, and the opposite is also true. Referring to this hypothesis, we understand that the political and social instability of the province of Upper Katanga, comes from the instability that families are experiencing at the moment. It is justified by a growing and high number of blended families for one reason or another. Family recompositions have the common denominator "separation". It is due in most cases to a divorce (Dolto, 1988), but also to widowhood or to early adventures and disappointments in love.

The family recomposition poses serious problems of nonpeaceful cohabitation between parents-in-law and children, half-brothers and half-sisters, quasi-brothers and quasisisters and the legitimacy or privileged status of the German brothers (Kakunda, 2014).

\subsection{Main angles of view on the family}

From the point of view of study, the family is a complex object of understanding and practice. It involves dimensions that are perceived according to different angles of view. These are the following: socio-cultural, psychoanthropological, psychobiological and ethicophenomenological (Delage, 2008).

- The socio-cultural perspective involves the various configurations of the family in contemporary society.

- The psycho-anthropological angle of view to the combination of arrangements that imply the difference of the sexes and the difference of the generations, beyond the diversity.

- The psychobiological angle of view as a place that allows the development and maintenance of individual security.

- The ethico-phenomenological angle of view relates to the values, norms, beliefs to which all families refer and mobilize their energies.

\section{Specific concepts relating to representation}

\subsection{Notions}

In social psychology, the notion of "representation" occupies a prominent place today (Moliner, Rateau \& Cohen-Scali, 2002). Thus, in a sense frequently encountered, in philosophy or dominant in genetic psychology, representation is one of the forms of symbolic activity aimed at making an absent object present (Ferréol, 1991).

For cognitive psychology, representations are internalized models that the subject constructs of his environment and his actions on this environment. These models can be used by the individual as a source of information and instruments for regulating and planning their behavior (Michel, 2007).

Jodelet (1989: 36) considers that representation is "a form of knowledge, socially elaborated and shared, with a practical aim and contributing to the constitution of a reality common to a social ensemble".

There are several forms of representations, mental, individual, cognitive, collective, social, ..., the most studied of which are the social representations, which Moscovici (1961, pp. 27-28) defines as "organized corpora of knowledge and psychic activities through which men make physical and social reality intelligible, and which form part of a daily group or relationship of exchange, and which liberate the powers of their imagination. » Mannoni (2012, p.3) considers that "these kinds of representations are at the base of our psychic life, and are the essential pieces of our epistemology, at least as far as our knowledge of common sense is concerned. Located at the interface of the psychological and sociological, social representations are rooted in the heart of the social system, including the family.

\subsection{Information elements constituting the representation}

Bouedec (1984) considers that in the mental universe, every representation is composed of elements that are organized by multiple relationships. Two categories of elements are distinguished, the constituent elements of any representation, called "central core" and "peripheral elements".

This central nucleus generates the meaning, the organization and the coherence of the representation. It is linked to the historical, social, emotional and ideological conditions in which it evolves. It is the stable, consensual and normative part. Around the latter, a large number of elements called "peripheral elements" are organized, which play an interface role with the central nucleus. They correspond to the concrete and functional part of the representation. They make it possible to understand that individuals from the same group can engage in different behaviors (MichelGuillou, 2005).

\section{Methodology}

\subsection{Participants}

In 2013, a survey of 50 students from blended families, including 19 students and 31 students, from UNILU took part in this survey, and made verbal productions around the

\section{Volume 6 Issue 12, December 2017}




\section{International Journal of Science and Research (IJSR) \\ ISSN (Online): 2319-7064}

Index Copernicus Value (2016): 79.57 | Impact Factor (2015): 6.391

concept of "stepfamily". The average age is 23 years old. They are divided into three categories of sciences: 11 life sciences ( 2 students and 9 students), 6 sciences ( 2 students and 4 students) and 33 human sciences (14 students and 19 students).

We opted for the so-called empirical sampling technique. It allowed us to conduct surveys of students who were well identified based on two criteria, namely:

1) Belong to a stepfamily;

2) And then be kassapards.

\subsection{Investigation procedure}

To carry out this research, we used the prototypical and categorical analysis devised by De Rosa in 1995 (Moliner, Rateau \& Cohen-Scali, 2002). That's how we used it concretely:

1) Give a piece of paper to the respondents, on which we had written in the middle the inductive word: "stepfamily".

2) Ask the respondents:

a) To produce 5 associations (word or expression) that came to their mind from the word inductor.

b) To enter the order of appearance.

c) Indicate the sign + (positive) or - (negative), to determine the connotation of these associations.

d) To classify the terms produced in order of importance, which makes it possible to determine the rank of appearance, as a major indicator of the importance of the words expressed.

3) Organize a non-directive interview starting from the associations made, which lasted on average from 30 to 45 minutes.

\subsection{Data analysis procedure}

The prototypical and categorical analysis allowed us to summarize and organize our data. She lent herself better to this structural study on representations of the stepfamily. It also allowed us to apprehend and constitute the semantic universe of our object of study.

Overall, we were able to collect 250 productions, with 5 productions per interviewee.

The total number of different themes (words or phrases, after a semantic categorization) is 7 . This is the family in which we live:

1) On new bases

2) With too many negative values

3) By changing the starting structure of a family

4) After a breakdown of the first marriage

5) With any lack

6) With new members

7) With a polygamous parent
The frequency (the number of times this theme has been produced) has been recorded for each of these themes (see Table 1). The average frequency per theme is 35.7 , or $250 / 7$. Thus, it is to be considered that the themes which will have an average frequency inferior to 35,7 will be regarded as productions which are the least considered, and those which will have an average frequency greater than or equal to 35,7 are productions which are the more considered.

In addition to this, we have determined the average rank of appearance of each theme, on the whole population, and this one rises to 3 .

As a result, themes with an average rank of less than 3 will be considered associations that are listed first, and those with an average rank greater than or equal to 3 are associations that are listed last.

\section{Results}

In view of the above, the crossing of the frequency and the average rank makes it possible to obtain the table $n^{\circ} 1$. The appearance frequencies of the themes are placed in parentheses.

Table 1: Theoretical table of analysis of hierarchical evocations

\begin{tabular}{|c|c|c|c|}
\hline & \multicolumn{2}{|l|}{ evocatic } \\
\hline & & \multicolumn{2}{|c|}{ Average rank } \\
\hline & & Inférieur à 3 & Egal ou Supérieur à 3 \\
\hline \multirow[b]{2}{*}{ Frequency } & $\begin{array}{c}\text { Greater } \\
\text { than or } \\
\text { equal to } \\
35.7\end{array}$ & $\begin{array}{l}\text { Living with too } \\
\text { many negative } \\
\text { values (77) }\end{array}$ & $\begin{array}{l}\text { Living on a new } \\
\text { foundation }(\mathbf{1 0 4})\end{array}$ \\
\hline & $\begin{array}{c}\text { Less than } \\
35.7\end{array}$ & $\begin{array}{l}\text { Characterized by } \\
\text { polygamy }(\mathbf{6}) \\
\text { Having modified } \\
\text { the starting } \\
\text { structure of a } \\
\text { family }(\mathbf{2 3}) \\
\end{array}$ & $\begin{array}{c}\text { Out of first marriage } \\
(\mathbf{2 1}) \\
\text { Living with some } \\
\text { lack (9) } \\
\text { Reunites new } \\
\text { members (7) } \\
\end{array}$ \\
\hline
\end{tabular}

\section{Comment}

It emerges from this first table that the reconstituted family is considered for most cases as a family in which one is called to live on new bases, nevertheless, this conception was not produced among the first productions. The same is true of the conception which states that it is born after the break-up of the first marriage, it is a structure within which one lives with some lack, and it brings together new members. These three conceptions are little considered by the respondents. It is also considered as a family in which there are too many negative values. This is one of the first designs, as well as a family that has already changed its starting structure, and one of whose parents is polygamous. These two conceptions are more considered by the respondents. 
International Journal of Science and Research (IJSR)

ISSN (Online): 2319-7064

Index Copernicus Value (2016): 79.57 | Impact Factor (2015): 6.391

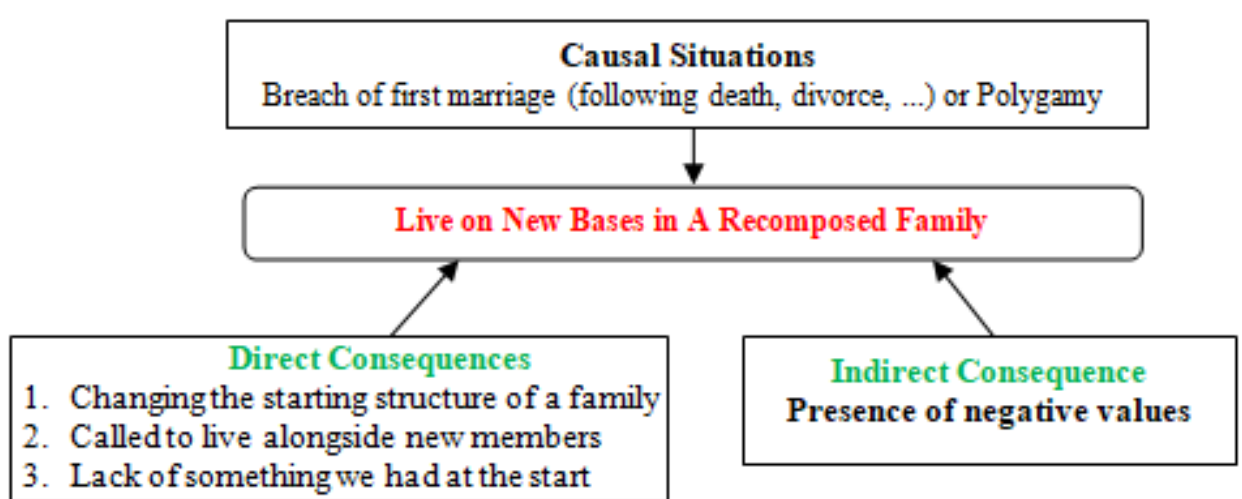

Figure 1: Diagram of the central core and the peripheral elements of the representation of the stepfamily

\section{Comment}

This schema shows that the central nucleus with regard to the representation of the stepfamily is the fact that one is called to live on new bases. This nucleus joins the peripheral elements reflecting the causal situations as well as the direct and indirect consequences of this phenomenon.

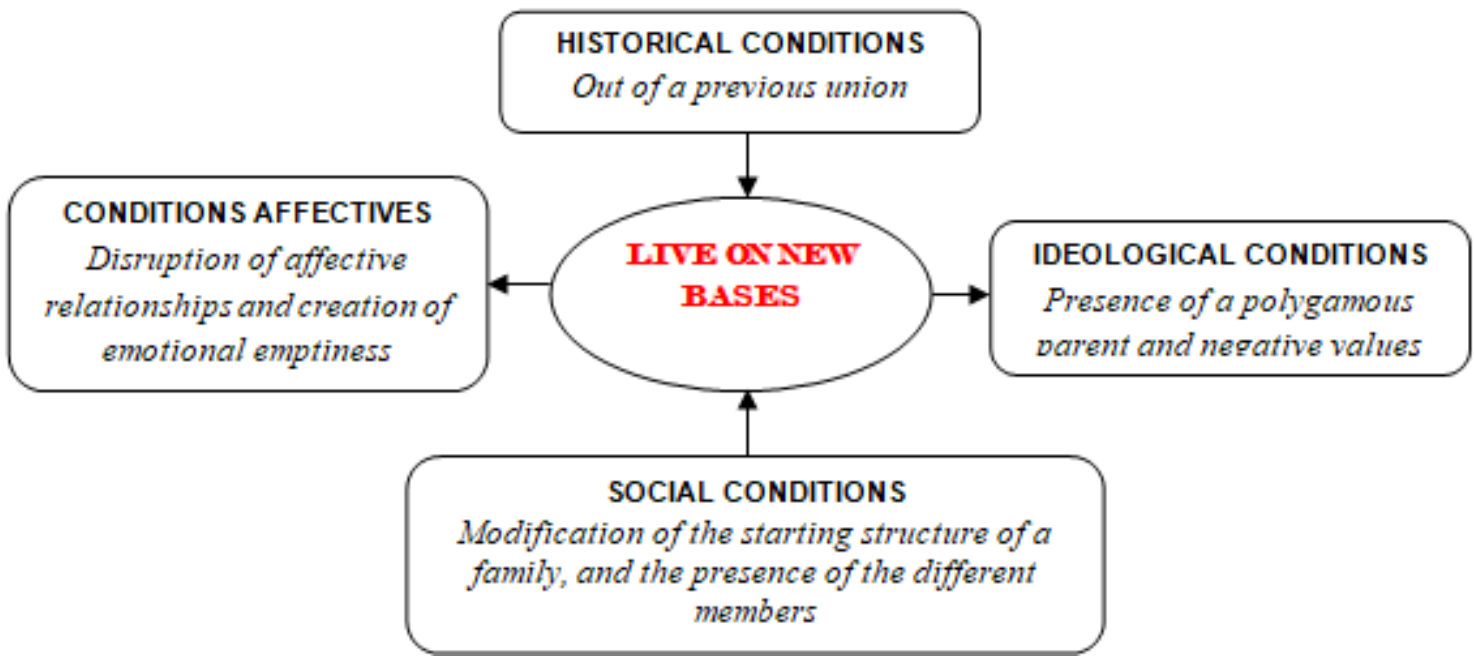

Figure 2: Diagram of the central core of the stepfamily and its different terms

This diagram presents the different conditions related to the central core of the representation of the reconstituted family as desired by Michel-Guillou (2005), based on the productions of UNILU students.

\section{Discussion}

This survey of nearly 50 students reveals that the stepfamily is more considered to be a family in which there are too many negative values, after having modified the starting structure of a family, because the family reconstituted to a family. particular configuration (Drory, 2009), which undermines all known patterns of family, with the presence of social parents (Heenen-Wolff, 2011), and for most of them one of the parents is polygamous, in the occurrence the father.

As Drory (2009, p.24) confirms, a blended family is not built without difficulty, this is why the respondents revealed during the interviews, that the blended family presents for most cases the negative values, notably: spouses (Drory, 2009), rivalry within the family (Drory, 2009), members experience a climate of anxiety that triggers a loss of bearings (Heenen-Wolff, 2011), nightmares that awaken the whole family (Dahin, 2013)., The traumatic events that come from sexual abuse, family dysfunction, emotional deprivation, abuse, ... (Le Breton, 2014).

They also referred to disputes, conflicts between children, discrimination between children or parents vis-à-vis other children, juvenile delinquency, child marriages and early pregnancies, in this case children. Girls, the non respect of the rules and the family norms by the different members, with the fugue of the children to become children of the street, admittedly, the stepfamily necessarily modifies the basic structure of a family, namely that composed of a father, a mother and children. The proof is that we are witnessing the combination of children from two or more unions of spouses (Audibert, 2009), or the combination of members from several families, in which we can find the great parents, uncles, aunts, nephews, nieces, cousins, cousins, even acquaintances. This conception makes us think of Merkel's definition of the reconstituted family as being the most complex, the most unnatural and the most delicate set of human relations in a nuclear family. Speaking of the polygamy of one of the spouses that is one of the causes, there may be added the cases of widowhood, divorce or early adventures and disappointments in love. (Dolto, 1988).

Apart from the above, the blended family allows different members to embark on new foundations different from those

\section{Volume 6 Issue 12, December 2017}

\section{www.ijsr.net}




\section{International Journal of Science and Research (IJSR) \\ ISSN (Online): 2319-7064}

Index Copernicus Value (2016): 79.57 | Impact Factor (2015): 6.391

they once had, because Drory (2009, p.24) believes that children must give up their hopes of reconciliation and must agree to have their parents devote themselves, at least in part, to someone other than themselves, whereas Eideliman (2009) believes that a family event can lead to a reorganization of family services and exchanges. Let's also say, as Dahin (2014) confirms, the stepfamily requires a development in this new union. Therefore, the first marriage must necessarily be broken, as Delage (2008) confirms to us that most of those who fail in their family seek to start over and make another family, which is therefore a stepfamily. It should also be added that in order to form this type of family, Drory (2009, p.24) believes that parents must mourn the previous couple, the mourning of the ideal nuclear family they had before. And no matter the origin of this break, on the one hand it really creates a void near the different members (parents and / or children), which for the most part can be emotional or social, that we can consider as a lack. We note that children experience emotional disturbance (Drory, 2009), emotional suffering (Le Breton, 2014) accompanied by concerns (Heenen-Wolff, 2011), whose origin is for the absence of a parent or his indifference (Le Breton, 2014). And on the other hand, the different members will necessarily form a new union, called step family, within which is noted the presence of a stepmother as confirmed by Heenen-Wolff $(2011,38)$, and siblings apart whole and / or half-germs (Widmer, 1995).

\section{Conclusion}

This article demonstrates the concrete application of prototypical and categorical analysis in the study of the representations that UNILU students make on stepfamily.

The results demonstrate, after analysis of the frequencies and ranks of different opinions, that there is a central core around this social phenomenon, to which two categories of peripheral elements join. These are the causal situations and consequences related to this phenomenon. On the other hand, this purely social phenomenon brings about important modifications, and generates remarkable social maneuvers near parents and / or children.

\section{References}

[1] Amout, M., (2005). Take care of the family Paris, Armand Colin.

[2] Audibert, C., (2009). Oedipus and narcissus in stepfamily. Psychic issues of the redial. Paris: Editions Payot.

[3] Bizige, C. (2012). Sexual identity from a physical and psychological point of view man and woman. Chemchem, 12, 23-39. Lubumbashi: Editions Don Bosco.

[4] Castellan, Y. (1982). The family. Paris: University Presses of France.

[5] Coslin, G., (2007). The socialization of the teenager. Paris: Armand Colin.

[6] Dahin, A-F., (2013). The victim in all its states. Brussels: Fabert.

[7] Delage, M., (2008). Family resilience Paris: Odile Jacob.
[8] Delage, M., (2013). The life of emotions and attachment in the family. Paris: Odile Jacob.

[9] Dolto, F., (1988). When the parents separate. Paris: Edition of the threshold.

[10] Drory, D., (2009). The child and parental separation. Brussels: Fabert.

[11] Duret, I. \& Lefebvre, A., (1997). Seeking real family, at any cost. History of a shameful filiation. Cahiers de psychologie clinique, 9, 55-69. Brussels: De Boeck \& Larcier s.a. ISBN 2-8041-2649-8.

[12] Eideliman, JS, (2009). Families to the test. French Ethnology, Vol. 39, 435-442. Paris: University Presses of France ISSN 0046-2616. DOI: 10.3917 / ethn.093.0435.

[13] Ferréol, G., Cauche, P., Duprez, J.-M., Gadrey, N. \& Simon, M. (Eds). (1991). Dictionary of sociology (3rd ed.): social representations. Paris: Armand Colin.

[14] Heenen-Wolff, S., (2011). Homoparentalités. Brussels: Fabert.

[15] Jodelet, D. (1989). Social representations: an expanding field, In D. Jodelet (Ed.), Social representations (pp. 31 - 61), Paris: PUF.

[16] Kakunda, L. (2014). The problem of peaceful coexistence between members of a stepfamily. L2 Peace Education, IUMM, Unpublished Memory.

[17] Kienge-Kienge, R. (2008). Family, law and society. Issues of legislative activity. Kinshasa: Kazi Editions.

[18] Bouedec, G., (1984). Contribution to the methodology of study of social representations. Cahiers de Psychologie Cognitive 4 (3), 245-272.

[19] Breton, D., (2014). Adolescence and risk behaviors. Brussels: Fabert.

[20] Leclerco, J. (1958). Natural Law Lesson III. The family. Namur and Leuven: Edition Wesmaël Charlier (SA).

[21] Lubwambu, J., (2013). The problem of a harmonious life in some blended families. G3 Peace Education, IUMM, TFC Unpublished.

[22] Mannoni, P. (2012). Social representations (6th ed.) Paris: University Presses La France.

[23] Michel, D. (2007). Mental representation or representation. In D. Bloch, H. et al. (Eds). Great dictionary of psychology. Paris: Larousse.

[24] Michel-Guillou, E. (2006). Social representations and social practices: the example of the pro-environmental commitment to agriculture. European Journal of Applied Psychology 56, 157-165.

[25] Moliner, P., Rateau, P., \& Cohen-Scali, V. (2002). Social representations: Practice of field studies. Jouve: University Presses of Rennes.

[26] Moscovici, S., (1961). Psychoanalysis, it's image and it's public; study on representation psychoanalysis. Paris: PUF.

[27] Vergès P. (1992). The evocation of money: a method for the definition of the central nucleus of a representation. Psychology Bulletin, 45, No. 405, 203 209.

[28] Widmer, E., (1995). Abel and Cain. Fraternal relationships in adolescence. Unpublished thesis, University of Geneva. 